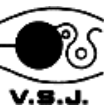

\title{
可変式旋回羽根付き予混合燃焼器内における 火炎の伝播挙動に関する研究*
}

\author{
市川 雄一 1)，小宮山 正治 1),2)，小山 敦史 1)
}

\section{Study on Flame Propagation Behavior}

\section{in a Premixed Combustor with Variable Swirl Vanes}

\begin{abstract}
Yuichi ICHIKAWA, Masaharu KOMIYAMA and Atsushi KOYAMA
ABSTRACT

Lean premixed combustion is one of the most promising techniques to reduce nitrogen oxide (NOx) emissions. However, lean premixed combustors have a narrow stable combustion range compared with diffusion combustors. So, a study on flame propagation behavior is an important issue for premixed combustion. In premixed combustors, swirling flow is typically used to stabilize the flame. In this study, we investigated the characteristics of flame behavior during changing swirl intensity in the cylindrical glass. We consider the effect of the following three factors on change of flow field and flame propagation behavior. The three factors are 1) swirl intensity strengthen or weaken, 2) the amount of swirl intensity change and 3) the speed of swirl intensity change. We clarify the interaction between flow field and flame propagation behavior during changing swirl intensity by applying high-speed PIV measurement.
\end{abstract}

Keywords : High-speed PIV, Flow and flame visualization, Flame propagation behavior

\section{1. はじめに}

近年, 二酸化炭素など温室効果ガスの増加が原因と考え られている地球温暖化やそれに伴う異常気象が大きな問 題となっている.さらに, 2011 年に発生した原子力発電 所における事故以降, 火力発電が果たす役割が大きくなっ ているため, 火力発電に用いられる産業用ガスタービンに は，更なる高効率化が求められている，そのため，燃料を 燃焼させる温度は上昇寸る傾向にあるが，それに伴って， 光化学スモッグや酸性雨の原因となる窒素酸化物 (NOx) の排出量は増加する. そこで, 産業用ガスタービンの一部 では希薄予混合燃焼が採用されている。予混合燃焼では, 従来用いられてきた拡散燃焼に比べて, 燃料と空気の混合 が不十分なために生じる局所的高温部を低減することが できるため, NOx 生成を抑制する効果がある。しかし, 予混合燃焼は火炎の安定範囲が狭く, 逆火や吹き飛びなど のデメリットがある. 逆火とは, 火炎が燃料や酸化剂の供 給方向に逆らって上流側へ伝播する現象であり, 燃料・酸 化剂供給部などを焼損させ機器の信頼性低下にも繋がる. そのため, 工業的には火炎の伝播限界が重要な要素の 1 つ

* 原稿受付 2015 年 7 月 15 日

1) 非会員 大阪大学 工学研究科 機械工学専攻（广565-0871 大 阪府吹田市山田丘 2-1, E- mail :

ichikawa@tran.mech.eng.osaka-u.ac.jp)

2) 正会員 岐皁大学 工学部 機械工学科
であり，火炎伝播の限界に関する報告(1), (2)がいくつかある。 それに加えて, 逆火発生のメカニズム解明のため基礎的な 現象として詳細に解析を行っている研究報告(3), (4)もある. また，逆火は火炎伝播の形態によって一般的に，(1)壁面 付近の境界層における火炎の伝播 ${ }^{(1)}$, (2)乱流燃焼速度の増 加による火炎伝播, (3)燃焼の不安定性に起因する火炎伝 播，(4)渦崩壊による火炎伝播に分けられる。特に，ガス タービン燃焼器において見られる旋回流を伴う流れ場で の逆火では, 渦崩壊による火炎伝播に起因するものが主要 なものとして捉えられている. 従来までの研究としては, 円管内で誘起される逆火に対して, 粒子画像流速計測法 (PIV) と OH-LIF 同時計測を行い，流れ場の可視化と火 炎面の位置を明らかにし, 周囲の再循環領域と火炎面の相 互関係を実験的に検証した結果, 再循環領域の先端におけ る流れ場の変化が逆火と密接に関連していることが報告 されている(5). 同様に PIV と OH-LIF の同時計測を渦心 の歳差運動（PVC）を伴う流れ場に適応し, PVC の周期 に合わせて変化する流速と $\mathrm{OH}$ 分布のパターンが明らか にされている(6)。また, 旋回を伴う燃焼器における流れを 実験的に分析し，一定燃料流量で空気流量を増加させた場 合のノズル出口に形成される円錐形状の予混合火炎の挙 動を観察した報告(7)もある。これらは旋回流を伴う流れ場 における逆火に注目したが，その強さが流れ場や火炎形状 
(本研究では火炎が存在する領域を指す) そして圧力変動 に与える影響も報告されている(8).このように, 火炎伝播 と流れ場は密接に関係しており, 互いに影響を与えている ことが明らかにされている.

筆者らは, 予混合燃焼器を模擬した円管内において, 一 定值に固定状態の旋回強さを発生させ, その条件下におけ る火炎先端 (本研究では最も上流側に存在する火炎面を指 す）の動的挙動と火炎周辺に存在する未燃予混合気の相互 関係を考察した ${ }^{(9)}$. そこでは, 火炎先端に存在する未燃予 混合気の流れ方向や流速が, 火炎の伝播方向や消炎の発生 に影響することを明らかにした，そこで本報では，旋回流 の旋回強さを変化させている間, 火炎先端に存在する未燃 予混合気の流れと, その時の火炎挙動を同時に捉え, 両者 の相互関係を明らかにすることを目的とした。そのため, 空気流量と空気比を固定した状態で, 旋回強さのみを変化 させている間の火炎伝播挙動について考察を行う.旋回流 中における火炎挙動は, 非定常な流れ場と火炎伝播が相互 干渉する複雑な現象である. 本実験では, 高速度カメラを 用いた時系列 PIV 計測を行い, 火炎形状と火炎周辺に存 在する未燃予混合気の流速分布を同時に且つ高い時間分 解能で連続的に取得した。

\section{2. 実験装置·方法}

実際のガスタービン燃焼器は複数の燃焼器から成って おり, 本研究では予混合燃焼が行われている燃焼器の 1 つ を模擬した実験用燃焼器（図 1) を対象に実験を行った。 燃料については, 多くのガスタービンで然料として用いら れている天然ガスの主成分であるメタン $\left(\mathrm{CH}_{4}\right)$ を用いた。 燃焼器底部より燃料と空気を別々に取り入れ, 燃焼器中心
軸にあり直径 $1 \mathrm{~mm}$ の穴が 18 個空けられた燃料ノズルか ら燃料を噴き出し, 周囲の空気と混合させ, その混合気を スワーラに通すことにより旋回を与えた. 本実験で用いた スワーラは図 2 で示すように, 36 枚の羽根から成り立っ ており, 羽根角度はステッピングモータによって制御でき, 旋回流の強さを独立に変化させることができる仕組みに なっている．このステッピングモータは, 後述の高速度カ メラによる撮影開始のトリガにもなっているため, ステッ ピングモータによる羽根角度の変化開始と同時に高速度 カメラの撮影が開始されるようになっている. そして, ス ワーラ通過後の未燃予混合気は, 燃焼器の閉鎖空間を模擬 したガラス円筒管（長さ $350 \mathrm{~mm}$ 内径 $60 \mathrm{~mm}$ ）の内部を 流れ大気中へ開放される.ガラス円筒管の材質については, レーザ光を透過し, 円筒管内部の火炎形状と流れ場を可視 化できるようにするため, 合成石英とした. また, ガラス 円筒管上端より $20 \mathrm{~mm}$ 上方に保炎器として直径 $12 \mathrm{~mm}$ のセラミック製円柱を設置した. 特に, 旋回強さを変化さ せた時における火炎先端の動的挙動と周囲の未燃予混合 気の流れ場を同時に捉えるため, 図 1 の斜線部が示すガラ ス管出口付近の領域に対して時系列 PIV 計測を導入し, 両者の相互関係について考察を行った。 また, 使用する座 標系については, ガラス管上端面における中心を原点とし, 半径方向に $x$ 軸を，ガラス管軸上方向に $y$ 軸を設定した.

次に, 図 1 に示した実験用燃焼器を含む全体的な実験装 置について, その概念図である図 3 を用いて述べる. PIV 計測とは, 流れ場に混入させたトレーサ粒子がレーザシー 卜面内を移動する量から面内 2 次元速度成分を測定する 手法である. 本実験では，このトレーサ粒子として直径約 $1 \mu \mathrm{m}$ のオリーブオイル粒子(10)を利用し, 図 3 が示すよう

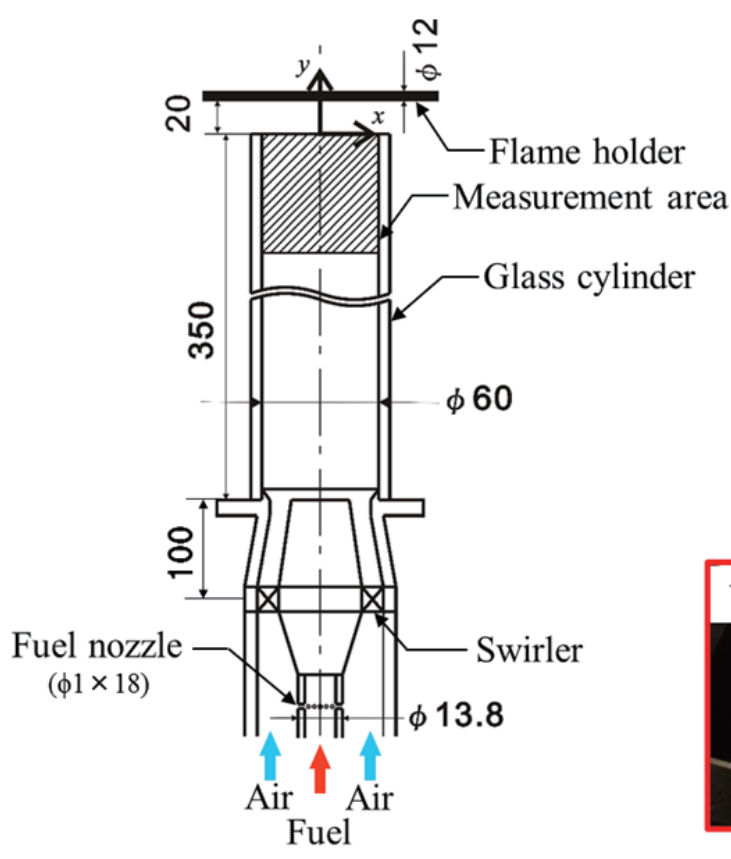

Fig.1 Schematic view of combustor.
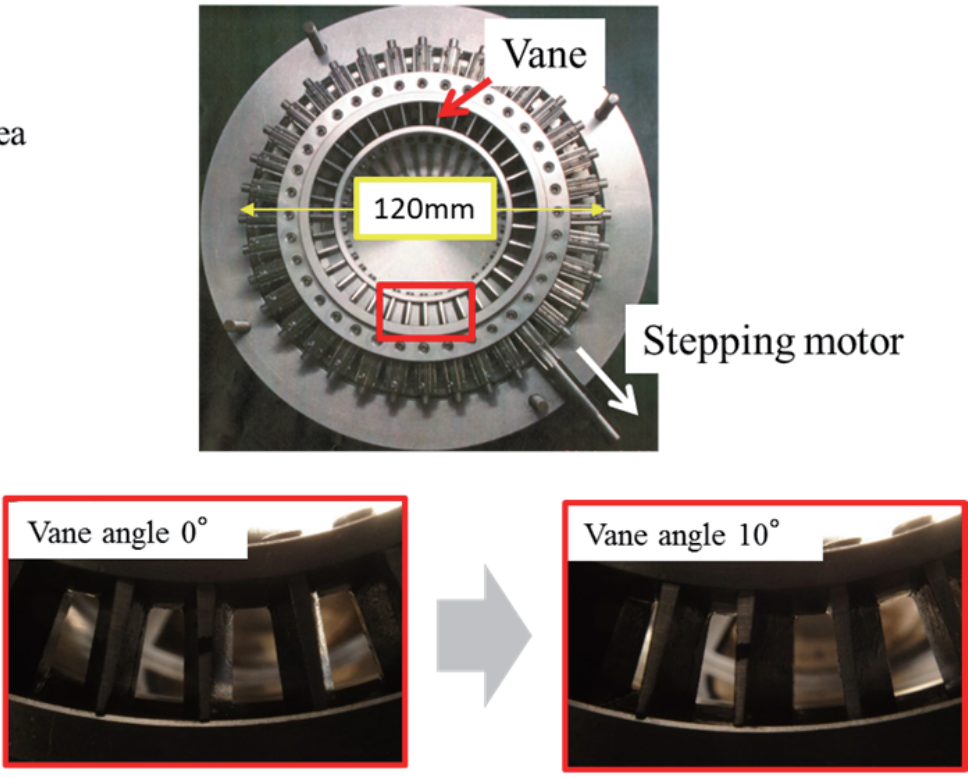

Fig.2 Vane angle-controllable swirler by stepping motor. 


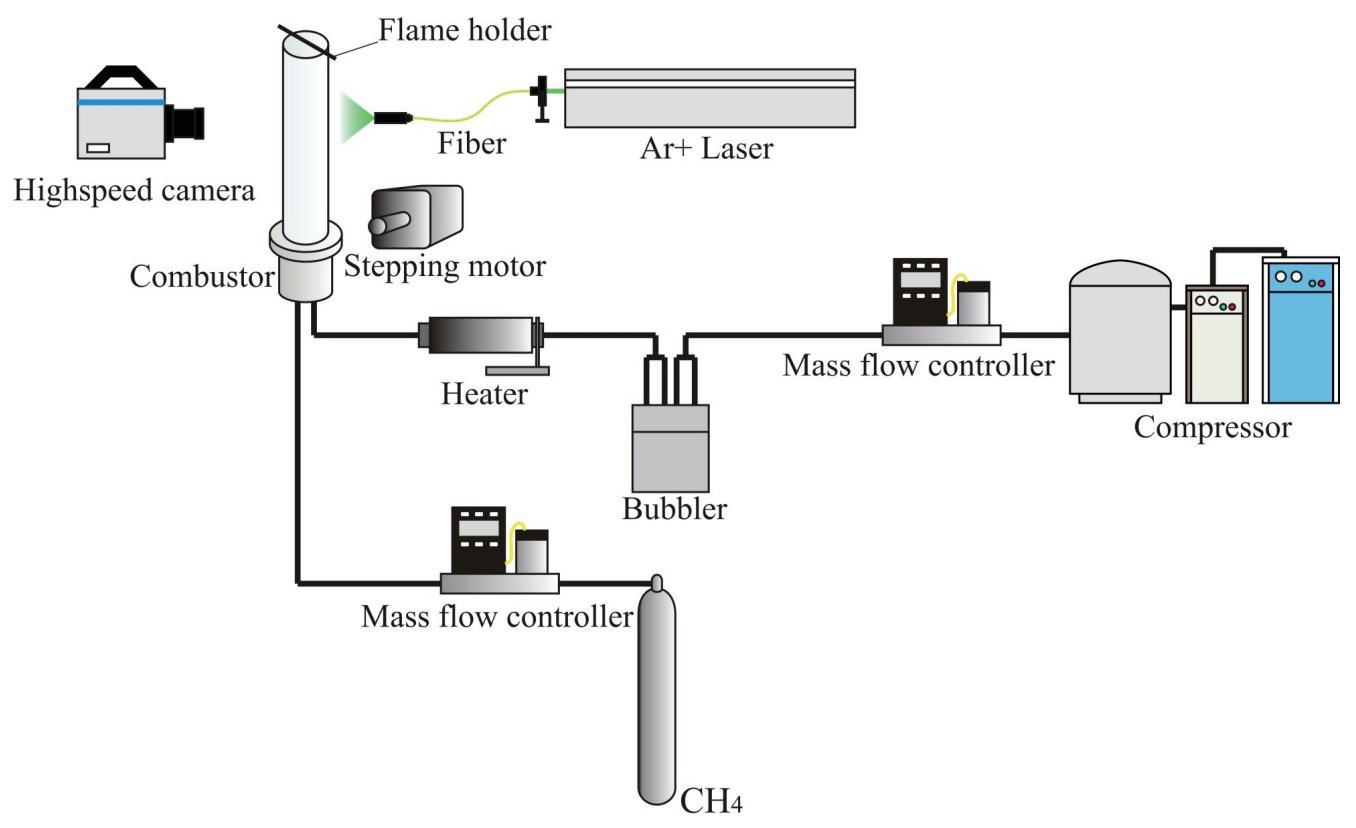

Fig.3 Experimental apparatus for time-series PIV measurement.

に,コンプレッサから供給された空気に混入させ実験用然 焼器に導いた。 トレーサ粒子については, オリーブオイル が満たされた圧力容器内に空気を供給し, ラスキンノズル を通して生成している.ここで生成したトレーサ粒子の追 随性については, 周波数応答や重力による影響そして遠心 力による影響について考察したが, $1 \mu \mathrm{m}$ のレーサ粒子を 利用する場合は, 重力や遠心力による影響は無視でき, 高 い周波数変動を持つ流れでも解析できる(11).また, オリー ブオイル粒子は，可燃性であり火炎中では焼失するため, 流れ場と同時に火炎形状を取得することが可能である.

PIV 用の光源には波長 $514.5 \mathrm{~nm}$ の連続発振 Ar+レーザ （Spectra Physics 社製 Stabilite2017，定格出力 6W) を 用いた. このレーザ光をファイバに入射させ, ファイバ出 ロに取り付けたコリメータによって厚さ $1 \mathrm{~mm}$ のレーザ シートを作成した. また, ガラス管からの反射を防ぐため, 測定範囲に対して斜め下方よりシート状のレーザ光を照 射した.さらに，トレーサ粒子からの散乱光強度を測定す る高速度カメラ（Photoron 社製 FASTCAM SA-3 model $120 \mathrm{~K}-\mathrm{M} 21024 \times 1024$ pixels）をレーザシート前面に配置 し, 前方散乱光を検出することにより，トレーサ粒子から の散乱光強度を強め,相対的にガラス管表面における反射 の影響を低減した. 本撮影における空間分解能は高速度力 メラのピクセル間距離に相当し約 $0.16 \mathrm{~mm}$ であった. 撮 影速度については, 検出可能最小速度が空気流量 Q air から 算出される平均流速 Vave（本実験では流量を $Q_{\text {air }}=50$ $\mathrm{NL} / \mathrm{min}$ としたため, Vave $=0.3 \mathrm{~m} / \mathrm{s}$ ) の 1/10であり, 同 じく平均流速にて動いたトレーサ粒子が厚さ $1 \mathrm{~mm}$ のレ ーザシートを突き抜けるために必要な時間の $1 / 10$ 程度に なる条件である $2000 \mathrm{frame} / \mathrm{s}$ とした. また, 粒子画像の
変位ベクトルを算出するため, 変位ベクトル計測処理に再 帰的相互相関処理を利用した。また，曲率半径の小さい円 筒管内での PIV では, 円筒面上でのレーザ光の反射とト レーサ粒子像が重なるため, 正しく速度ベクトルを算出す ることが困難となる，そこで，本研究では円筒管からの反 射の影響を低減するために, 粒子を含んだ未燃予混合気を 流さない状態にて石英ガラス管にレーザ光を照射させた 画像を取得し, トレーサ粒子画像から反射による光強度を 差し引いている.

実験条件については, 未燃状態におけるガラス管出口温 度を $293 \mathrm{~K}$, 空気流量 Q air $50 \mathrm{NL} / \mathrm{min}$, 燃料流量 Qfuel については旋回強さ変化前において逆火に至る限界值に 設定した. 本実験では, 旋回強さを表す指標としてスワー 儿数 $S$ を用い, スワーラ形状 $\left(R_{i}\right.$ : 内径 $R_{o}$ : 外径 $)$ と羽 根角度 $\alpha$ の幾何的情報から式(1)を用いて算出した ${ }^{(12)}$ 。

$$
S=\frac{2}{3} \tan \alpha \frac{1-R^{3}}{1-R^{2}} \quad\left(R=R_{i} / R_{o}\right)
$$

旋回強さを変化させている間における火炎の伝播挙動を 考察するにあたり, 本実験では，1)旋回強さの強めたまた は弱めたことによる影響，2)旋回強さの変化量による影響， 3)旋回強さを変化させる速さによる影響を検討した. 旋回 強さ変化の速さについては, "Slow”条件（約 9 degree/s） と"Fast”条件 (約 75 degree/s）の 2 種類を検討した。 そ の詳細については, ステッピングモータと同期させた旋回 羽根の形状を高速度カメラで撮影をし, その結果に基づい た羽根角度の時間的変化である図 4 に示寸. 具体的な実験 条件については，表 1 にまとめた。 
Table 1 Experimental conditions.

\begin{tabular}{|c|c|c|}
\hline & $\begin{array}{c}\text { Change of swirler vane angle } \\
\text { [degrees] } \\
\text { (Change of swirl number [-] })\end{array}$ & $\begin{array}{c}\text { Speed of swirl } \\
\text { intensity } \\
\text { change }\end{array}$ \\
\hline $\mathrm{A}$ & $25 \rightarrow 35(0.421 \rightarrow 0.633)$ & "Slow" \\
\hline $\mathrm{B}$ & $25 \rightarrow 35(0.421 \rightarrow 0.633)$ & "Fast" \\
\hline $\mathrm{C}$ & $25 \rightarrow 45(0.421 \rightarrow 0.904)$ & "Fast" \\
\hline $\mathrm{D}$ & $35 \rightarrow 25(0.633 \rightarrow 0.421)$ & "Slow" \\
\hline $\mathrm{E}$ & $35 \rightarrow 25(0.633 \rightarrow 0.421)$ & "Fast" \\
\hline
\end{tabular}

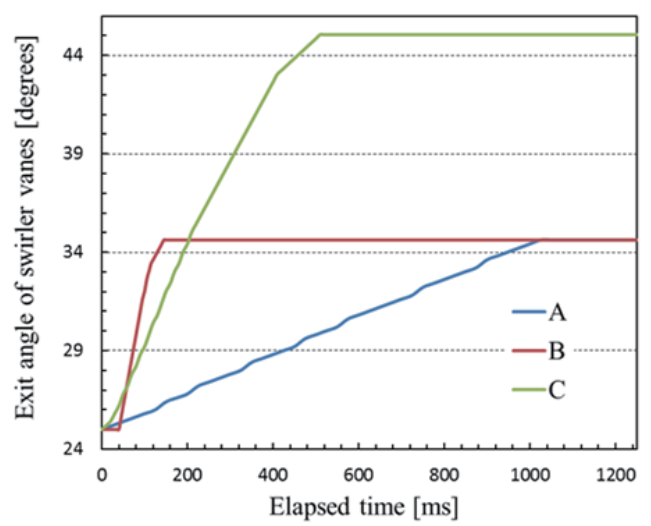

(a)Strengthening swirl intensity

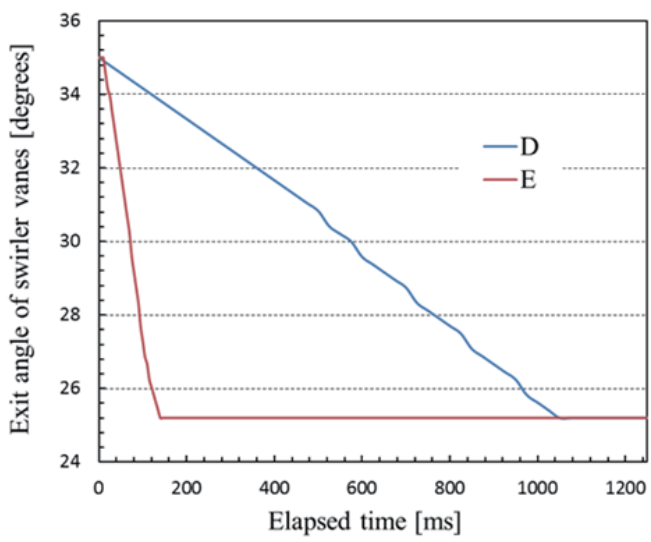

(b)Weakening swirl intensity

Fig. 4 The change of swirler vane angle under each experimental condition.

\section{3. 結果·考察}

図 5 は，未燃焼場における PIV 計測から得られた瞬時 の流れ場を時系列に並べたものである。この図中では, 疑 似カラーによってガラス管軸（ $y$ 軸）方向速度の分布を表 しており，上（下流）方向を正とし赤色で，下（上流）方 向を負とし青色で示している. 各図中の $t$ は羽根角度を変 化させ始めた時からの時間経過を示している。 また, 図 5(a) (e)は，それぞれ実験条件 A E に対応している. 全条 件とも左端の図は, 旋回強さ变化が計測範囲の流れ場に影
響を与える以前の結果である．また，以下に述べる旋回強 さを変化させている間に起った流れ場の変化や火炎挙動 は, 発生時刻こそ異なるものの, 複数回の実験にて確認で きている現象である.

まず初めに，スワール数 $S=0.421$ から $S=0.633$ 几旋 回強さを強めた条件について述べる. 図 $5(\mathrm{a})$ と(b)では, 旋回強さを強める速さに関する条件が異なり, それぞ れ”Slow”条件(約 9 degree/s) と” Fast”条件(約 75 degree/s) である. 燃料流量 Q fuel については, $S=0.421$ において逆 火に至る限界值（空気比 $\lambda=1.87 ）$ とした. 図 $5(\mathrm{a})$ と $(\mathrm{b})$ におけるすべての瞬時場において, 旋回流の中心軸に形成 される再循環流れの影響によって, ガラス管中心軸に沿う 低速領域 (本研究では速さが $0.2 \mathrm{~m} / \mathrm{s}$ 以下の領域を指す) または逆流領域を見ることができる. 図 $5(\mathrm{a})$ 中の $t=873$ $\mathrm{ms}$ において, 低速領域の半径方向への幅が, 以前のもの と比べて広がっていることがわかる.さらに, $t=1038 \mathrm{~ms}$ では, 中心軸上に上流への逆流を示寸青い疑似カラーが計 測領域の縦に広く分布するようになっている. しかし, 次 の $t=1362 \mathrm{~ms}$ では, 逆流領域が途切れ, 先ほどの縦に広 く分布する逆流は一時的であったものと考えられる.

図 5(b)では，条件 A と同様に時間の進行に従い，低速 領域または逆流領域の幅が広がっていることが確認でき る。しかし, ”Fast”条件では, 図 5(a)の $t=873 \mathrm{~ms}$ にお ける瞬時場のような, 逆流がはっきり見られない状態で低 速領域の幅が広がったのみという過渡的な瞬間は, 本実験 の撮影条件では確認できなかった。 その一方で, 図 5(b) の $t=648 \mathrm{~ms}$ の結果が示すように, 低速領域の拡大と共 に逆流が起こっている.さらに，t=1119 msでは，その 逆流がより強くなり, 流速が速く逆流領域も広くなってい る. しかし, 図 5(a) と同様に, この強い逆流は一時的であ り, 低速領域の更なる拡大と共に, 逆流の流速が小さくな ることが $t=1260 \mathrm{~ms}$ における瞬時場からわかる.

次に, 旋回強さを強める量を変えた場合の影響を見るた め, 条件 Cの結果を示した図 5(c)について述べる.ここで は，スワール数を $S=0.421$ から先ほどの条件 A と B よ り大きい $S=0.904$ 入旋回強さを強めた．その時の速さに 関する条件は，条件 B と同じ”Fast”条件である。また，燃 料流量についても, 条件 A と B と同様に $S=0.421$ にお いて逆火に至る限界值である空気比入 $=1.87$ に設定した。 図 $5(\mathrm{c})$ 中の $t=750 \mathrm{~ms}$ における瞬時場が示すように, 条 件 B よりも強い逆流が生じていることがわかる.また, $t=$ $849 \mathrm{~ms}$ では, ガラス管中心軸の流れが非常に乱れている ことがわかる.これは, $t=750 \mathrm{~ms}$ で発生した強い逆流に よって, ガラス管壁側に存在する下流への流れとの間にせ ん断流が生じ，それによって発生した渦が，ガラス管中心 軸付近の流れを乱していると考えられる. その後, $t=1107$ $\mathrm{ms}$ の結果から, 計測領域の縦全体にわたって条件 Bより も強い逆流が形成されることが確認できる. そして, $t=$ 


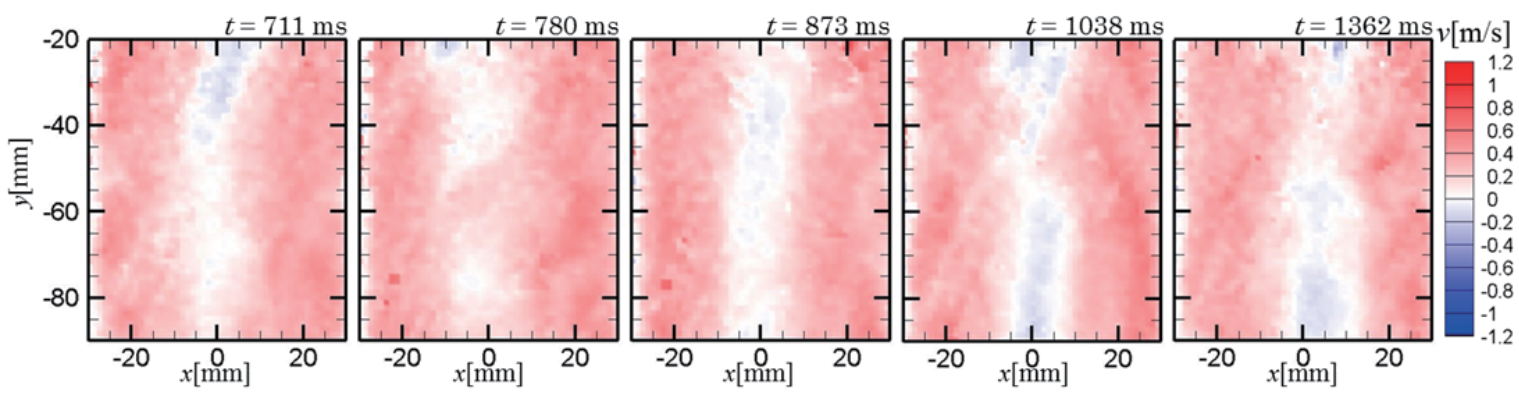

(a) Condition A

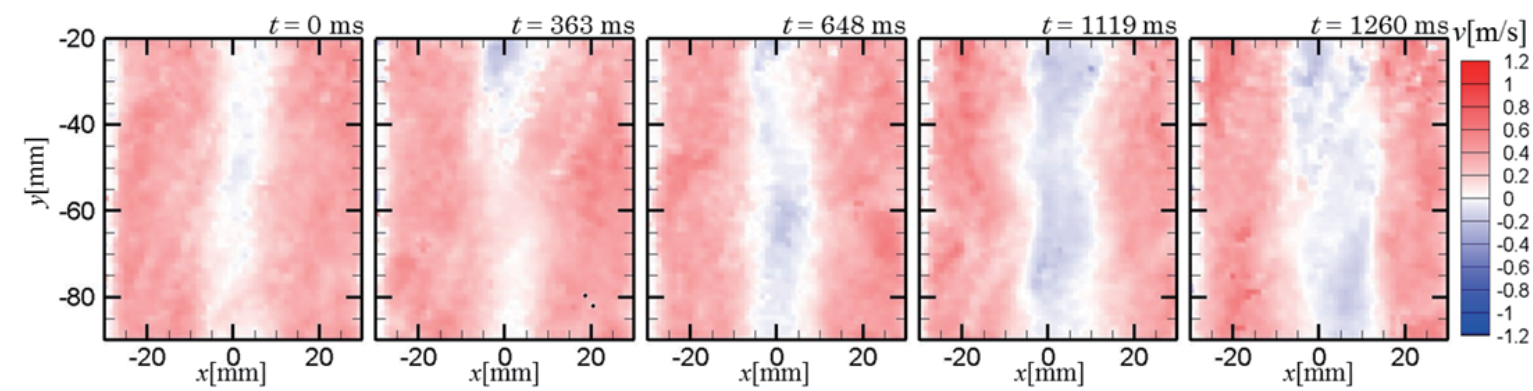

(b) Condition B

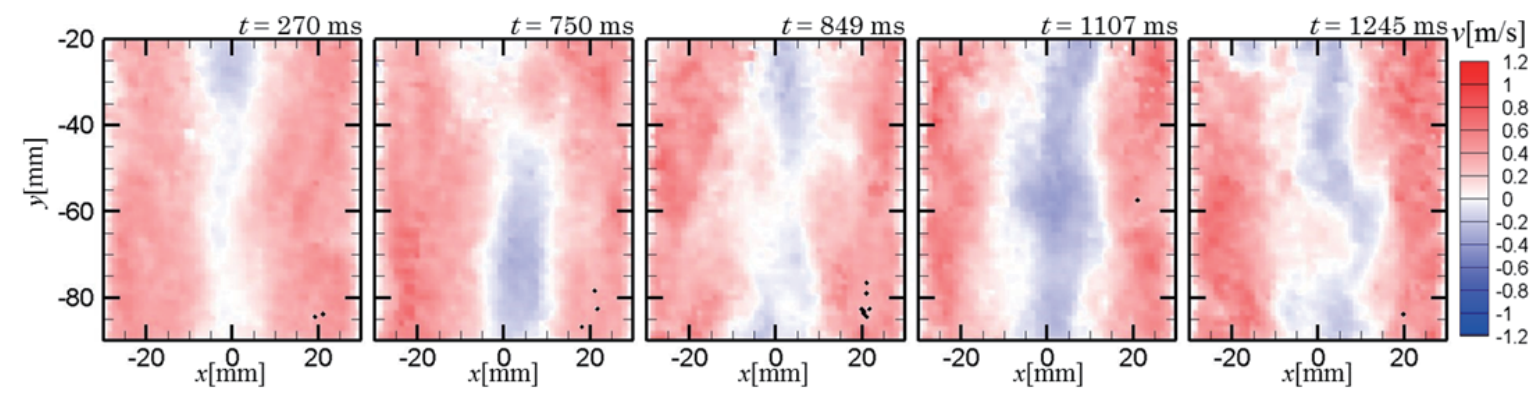

(c) Condition C

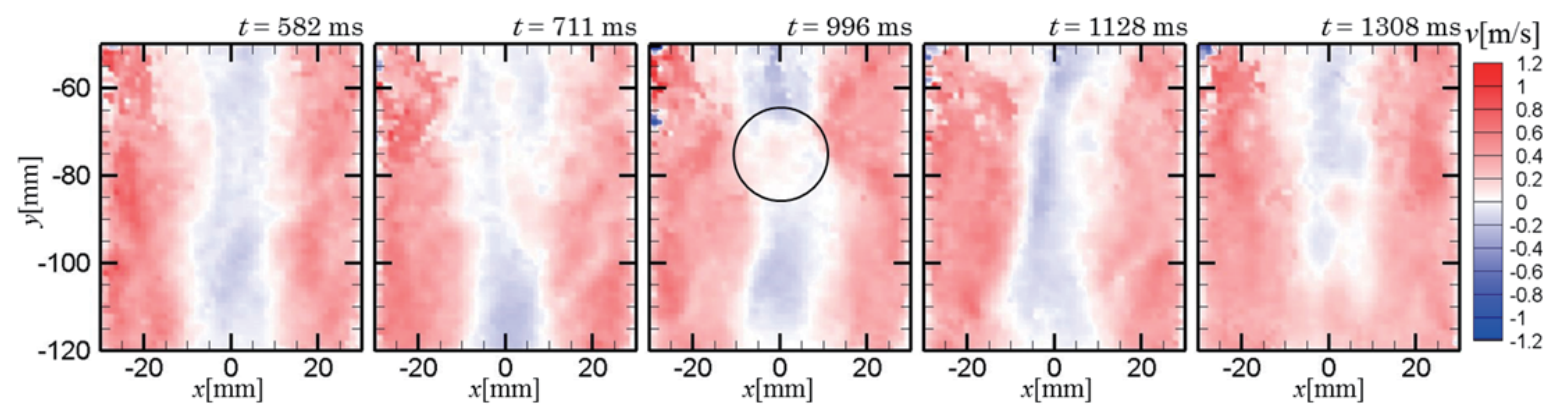

(d) Condition D

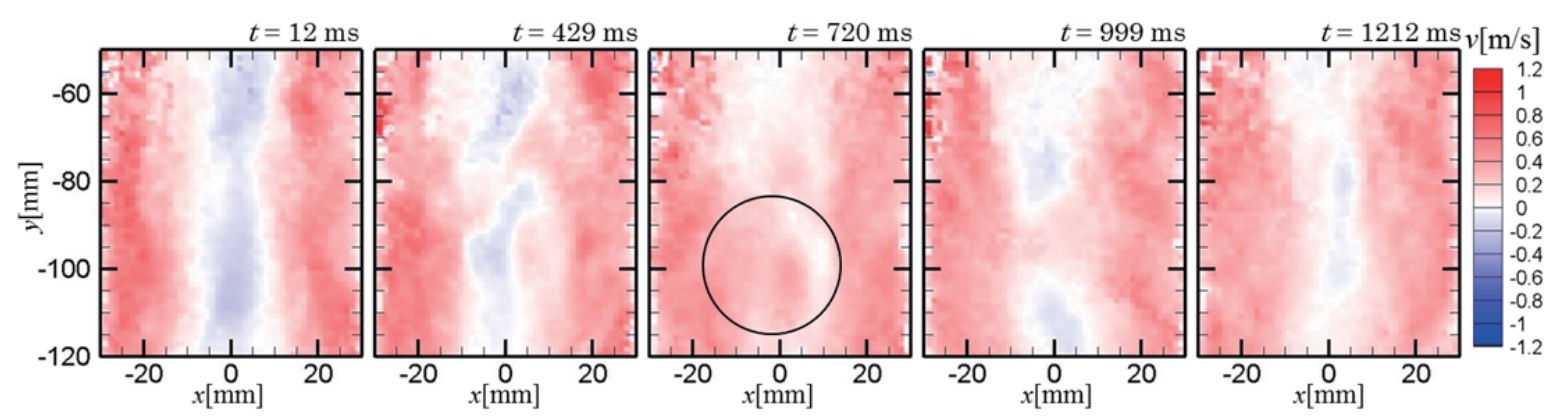

(e) Condition $\mathrm{E}$

Fig.5 Time-series flow fields during changing swirl intensity. 
$1245 \mathrm{~ms}$ では, 先ほどのせん断流が原因と考えられる流れ の乱れが, $t=849 \mathrm{~ms}$ の結果より顕著となり, 旋回流の渦 心を示寸逆流領域が湾曲している。

そして, 未燃焼場における考察の最後に, スワール数 $S$ $=0.633$ から $S=0.421$ 一旋回強さを弱めた条件 D と $\mathrm{E}$ について述べる. 条件 D と E は，旋回強さを弱める速さ を異なる条件にしたものであり，それぞれ”Slow”条件 と”Fast”条件下の結果である, 燃料流量については，S= 0.633 において逆火に至る限界值（空気比 $\lambda=1.92 ）$ とし た. 図 $5(\mathrm{~d})$ においては, 旋回強さを弱めた後, $t=582 \mathrm{~ms}$ や $t=711 \mathrm{~ms}$ の結果において見られるように，ガラス管 中心軸付近では，上流への逆流がしばらく支配的であるこ とがわかる. しかし, その後, $t=996 \mathrm{~ms}$ では, その中心 軸上に沿ってできた逆流を下流への流れが遮る部分 $(y=$ $-70 \mathrm{~mm}$ 付近, 図中の丸部分）が見られるようになる. 次 の $t=1128 \mathrm{~ms}$ では, 再びガラス管中心軸付近で逆流が支 配的になるが, その半径方向の幅は, 初期のものと比べて 狭いことがわかる. その後の $t=1308 \mathrm{~ms}$ では, 逆流が弱 まりその流速も領域も小さくなっている.

一方，条件 $\mathrm{E}$ の結果を示寸図 $5(\mathrm{e})$ では，条件 D よりも 早期に中心軸上に存在する逆流を下流への流れが遮り, 流 速分布がより複雑になっていることから, 流れがより激し く乱れていることがわかる. また， $t=720 \mathrm{~ms}$ における瞬 時場が示すように, 計測領域の全体にわたって下流への流 れとなっており (図中の丸部分), 単に旋回流の勢いが弱 まったのではなく, 渦構造が広範囲に崩壊していると考え られる.これは, "Slow”条件下では見られなかった流速分 布である。しかし，その後，ガラス管中心軸付近では，こ の強い下流への流れは弱くなり, $t=999 \mathrm{~ms}$ では, 低速領 域の一部を遮る程度にしかならない, さらに, 次の $t=$ $1212 \mathrm{~ms}$ では, 中心軸において下流への流れがほとんど見 られなくなる. また, 低速領域の幅が初期と比べて狭くな っており, 低速領域内での逆流もほぼなくなっている.

ここで, 図 5 で示した流速分布のある一点に着目して, $t=0 \mathrm{~ms}$ から $t=1362 \mathrm{~ms}$ における予混合気の流速につい て，その時間的変化を図 6 に示寸。この図中では，図 4 において示した羽根角度の時間的変化も一緒に示してい るので, 旋回強さの変化に対する流れ場の応答が明らかと なる. 図 6 においても, 各図(a) (e)は, それぞれ実験条件 $\mathrm{A} \sim \mathrm{E}$ に対応している. 着目した一点については, 図(a) (c) では $x=0 \mathrm{~mm}, y=-60 \mathrm{~mm}$ であり, 図(d)と(e)では $x=0$ $\mathrm{mm}, y=-80 \mathrm{~mm}$ の点とした.（この点とした理由は, 後 述する燃燒場の議論において火炎先端部分になるため.)

ここでも，実験条件 A の結果を示寸図 6(a)から述べる と, スワーラの羽根角度が旋回強さを強める方向へ変化し ている間は, 逆流はほとんど見られず, 羽根角度の変化が 終了したとほぼ同時刻に, 図 5(a)において述べた一時的な 逆流を観察することができる. 図 6(b)は，(a)に対して旋
回強さを変化させる速さのみを速めた結果である. 羽根角 度の変化が終了してから逆流が観察されるまで $400 \mathrm{~ms}$ 程 の遅れがあり, 図(a)とは異なる。また, 比較的大きい速 度分布の谷が複数あることから, 強い逆流が複数回現れ, 各回に現れる逆流の流速も条件 A において観察された逆 流の流速よりも速いことが明らかとなった.

次に, 図(b)よりも旋回強さ変化の量を多くした図(c)に ついて述べる. 図(b) と同様に”Fast”条件で旋回強さを変化 させたため, 羽根角度の変化が終了してから逆流が観察さ れるまで, 条件 B よりも少ないものの遅れが見られる. また，一時的に見られる強い逆流は，条件 B よりも強く 流速が速くなっていることがわかる.

一方，条件 A や B とは逆に旋回強さを弱めた時におけ る旋回強さの変化に対する流れ場の応答を以下に述べる. 図 6(d)が示すように, 条件 D では，旋回強さを弱める方 向に羽根角度を動かしている間も, 流速が $0.1 \mathrm{~m} / \mathrm{s}$ 以下の 低速ながらも下流への流れが頻繁に現れていることがわ かる. 条件 D と比べて旋回強さを弱める速さのみを速く した実験結果を示寸図 6(e)では，同様に”Fast”条件にて変 化させた図 6(b)や(c)にも見られたように, 羽根角度の変化 が終了してから, 流速が最大 $0.3 \mathrm{~m} / \mathrm{s}$ にも達する比較的強 い下流への流れが現れるまでには遅れが存在する, さらに， 図 6(d)では $t=0 \mathrm{~ms}$ から $t=1362 \mathrm{~ms}$ の全体を通して上 流への逆流と下流への流れが交互に入れ替わる一方, 図 6(e)では, $t=600 \mathrm{~ms}$ から $t=950 \mathrm{~ms}$ までの間，下流への 流れのみ現れていることがわかる.

次に, 旋回強さの変化が火炎の伝播挙動に及ぼす影響を, 未燃予混合気の流れ場との相互関係と共に示す。図 7 は, 既燃焼場において時系列 PIV 計測を行い，その結果を時 系列に並べたものである. 図 7 のような既燃焼場における 結果では, 未燃予混合気の軸方向流速を示す疑似カラーに 加えて, 火炎形状を黒い領域によって示した。 そして, 未 燃焼場の結果である図 5 と同様に，図 $7(\mathrm{a})$ (e)は，条件 $\mathrm{A} \sim \mathrm{E}$ に対応している.

ここでも，まずスワール数 $S=0.421$ から $S=0.633$ 人 旋回強さを強めた条件から述べる. 燃料流量 Q fuel につい ては, $S=0.421$ における逆火限界值（空気比 $\lambda=1.87 ）$ とした.また, 図 7(a)と(b)は, それぞれ”Slow”条件と”Fast” 条件である.ここでは, 特に火炎が $y=-30 \mathrm{~mm}$ から $y=-60$ $\mathrm{mm}$ 一火炎が伝播していくときに着目した結果と考察を 述べる. 図 7(a)における $t=333 \mathrm{~ms}$ の結果では, 未だ初 期状態から半径方向に幅が広がっていない低速領域へ, 細 長くなった火炎先端が入り込み始める様子が捉えられて いる. その後も火炎はその先端を尖らせたまま上流へと伝 播している様子がわかる。しかし， $t=495 \mathrm{~ms}$ のように, 下流へ流れる未燃予混合気が火炎先端に衝突すると火炎 先端は丸くなり, 火炎が横に広がると共に上流への火炎伝 播が止まる。一方, ”Fast”条件の結果である図 7(b)では, 


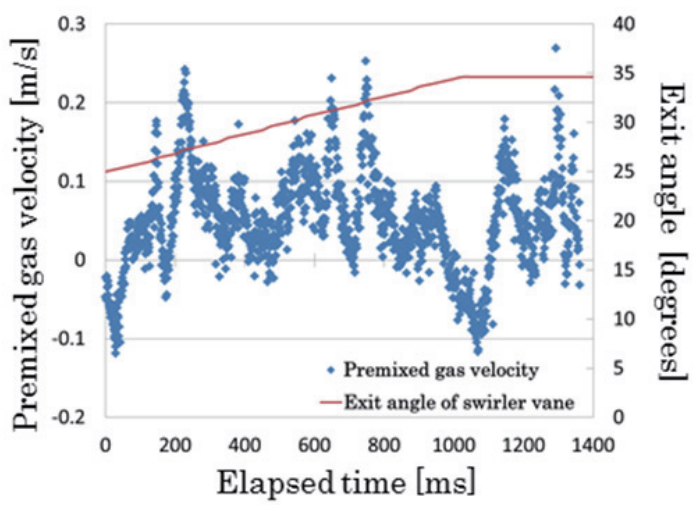

(a) Condition A ( $x=0 \mathrm{~mm}, y=-60 \mathrm{~mm})$

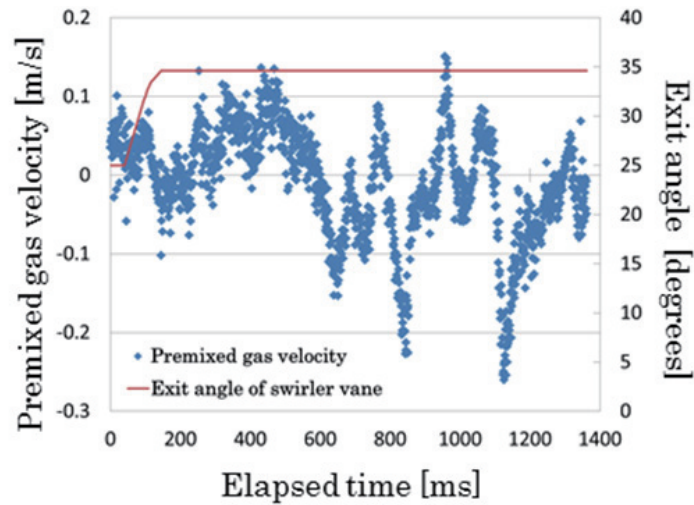

(b) Condition B ( $x=0 \mathrm{~mm}, y=-60 \mathrm{~mm})$

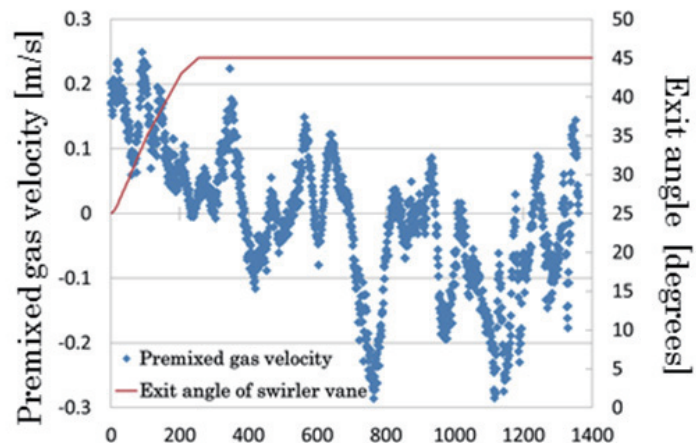

Elapsed time [ms]

(c) Condition C ( $x=0 \mathrm{~mm}, y=-60 \mathrm{~mm})$

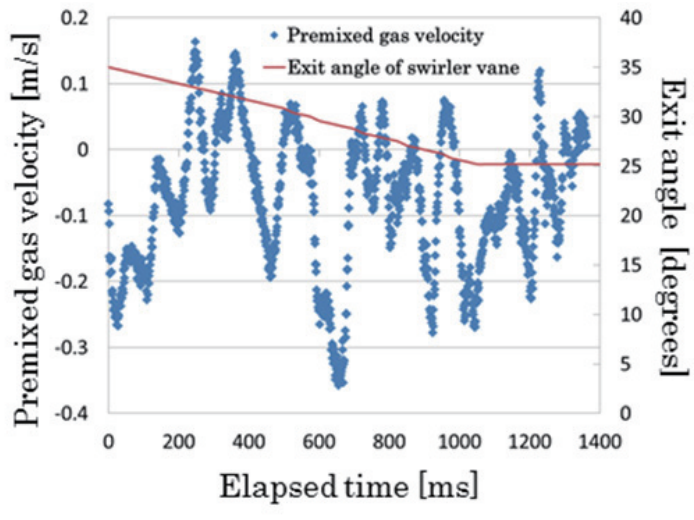

(d) Condition D ( $x=0 \mathrm{~mm}, y=-80 \mathrm{~mm})$

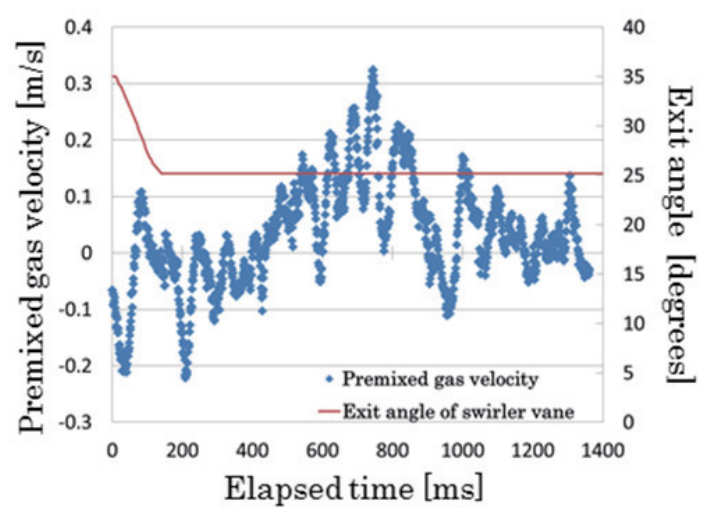

(e) Condition E ( $x=0 \mathrm{~mm}, y=-80 \mathrm{~mm})$

Fig. 6 Temporal variation of unburned premixed gas at a point and exit angle of swiler vanes.

$t=780 \mathrm{~ms}$ の瞬時場が示すように, 火炎先端の上流側に存 在する未燃予混合気の流れは上流方向であり, 逆流状態と なっている. その後, 火炎先端の形は, ”Slow”条件と比べ て大きく変わることはなく, 火炎先端の上流側に存在する 未燃予混合気の逆流によって, 一度も下流側へ戻ることも なく，上流側一火炎が一気に伝播していく様子が，その後 の結果から明らかとなった。これは, 火炎の燃焼速度と火 炎先端付近に存在する未燃予混合気が持つ流速とのつり 合いによって，上流へと逆流する未燃予混合気と共に，火 炎も上流側一と一気に伝播したと考えられる.さらに，旋
回強さを強める量が火炎伝播に与える影響を解明するた め, 条件 Cの結果を示した図 7(c)について述べる. 条件 B の結果である図 7(b) と比較すると, 火炎先端の上流側には, より強い未燃予混合気の逆流が常に存在している.ここで も, 火炎の燃焼速度と未燃予混合気の流速とのつり合いに よって, 図 7(b)より速い火炎伝播速度を伴って, 火炎が上 流側一伝播したと考えられる.

最後に, スワール数 $S=0.633$ から $S=0.421$ 一旋回強 さを弱めた条件 D と E について述べる.ここでは, 特に, 火炎が $y=-80 \mathrm{~mm}$ から $y=-60 \mathrm{~mm}$ 一伝播していくとき 


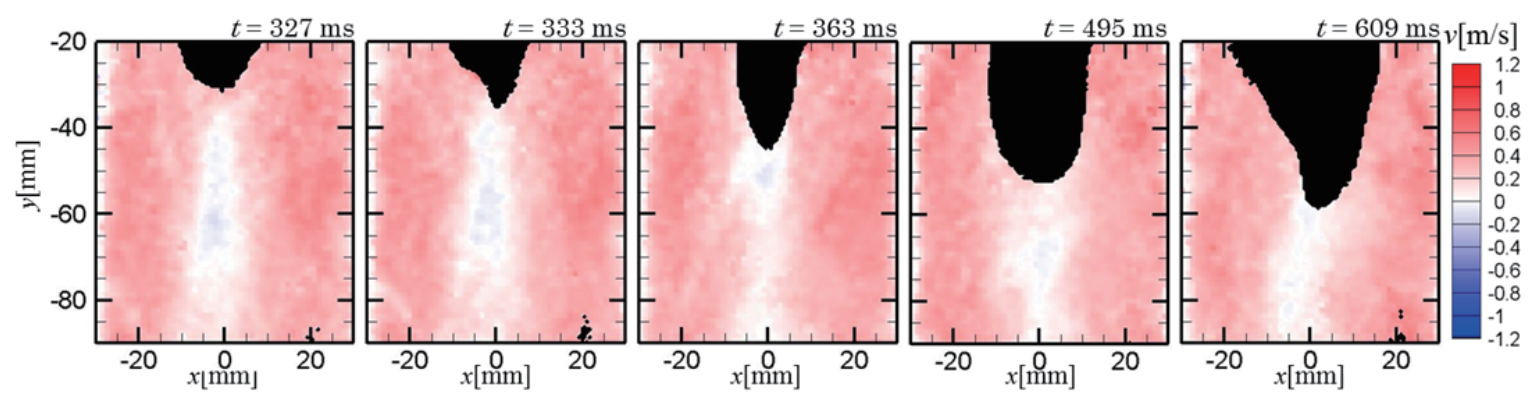

(a) Condition A

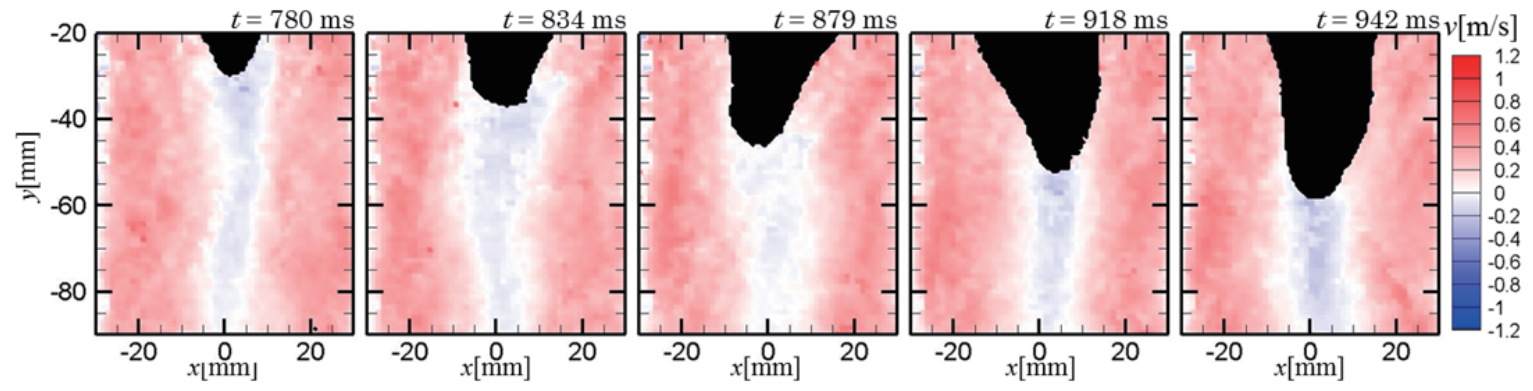

(b) Condition B

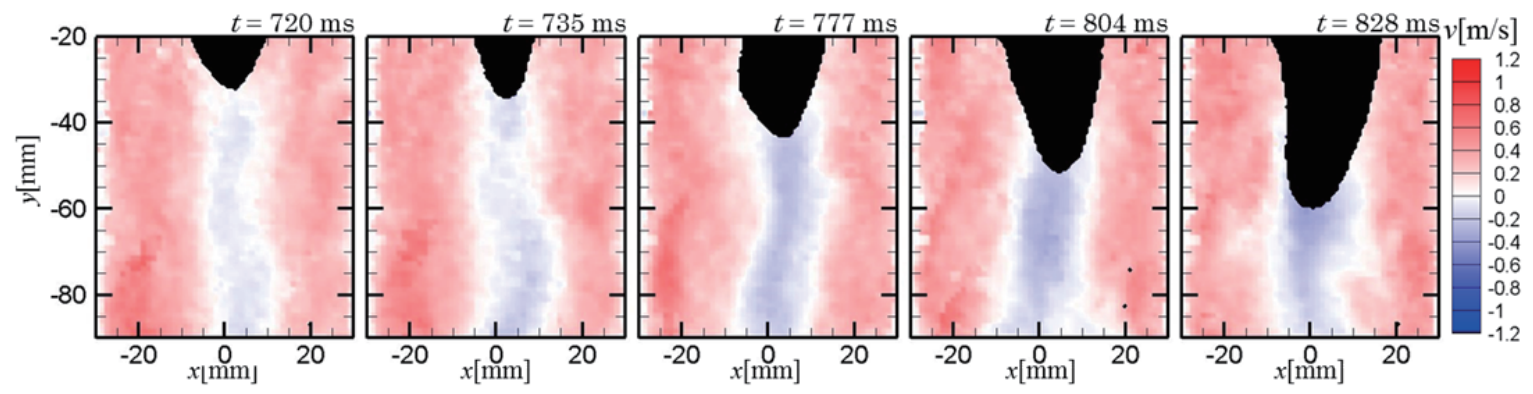

(c) Condition $\mathrm{C}$

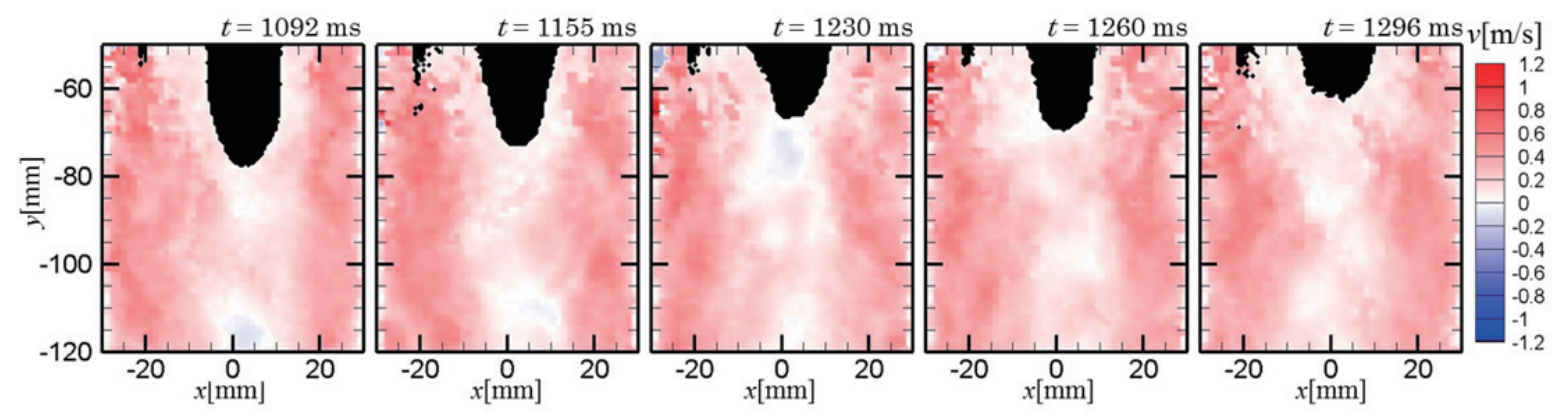

(d)Condition D

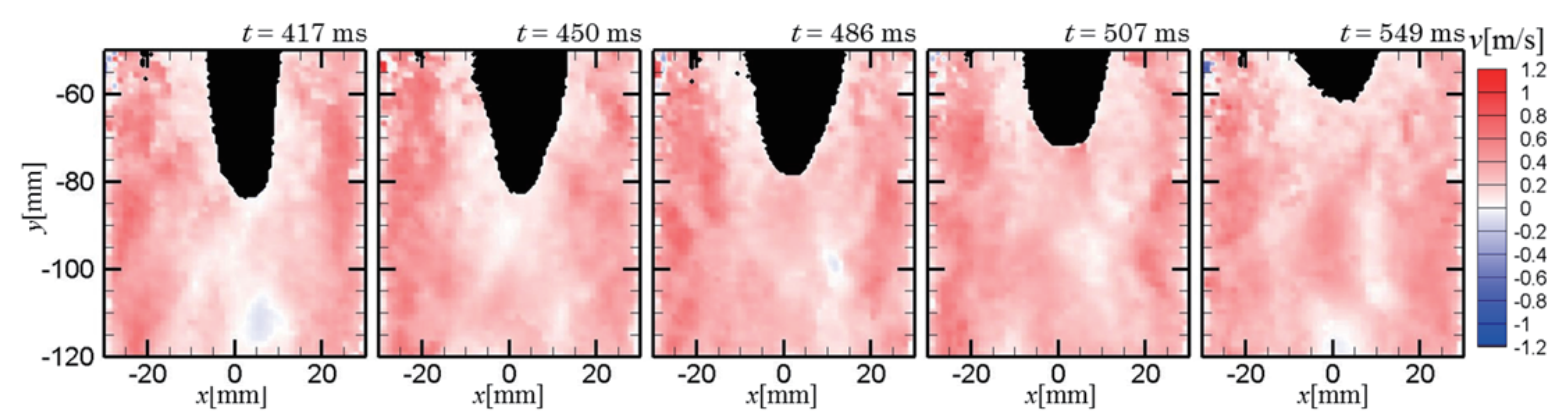

(e) Condition $\mathrm{E}$

Fig.7 Time-series flow fields and flame propagation behavior during changing swirl intensity. 


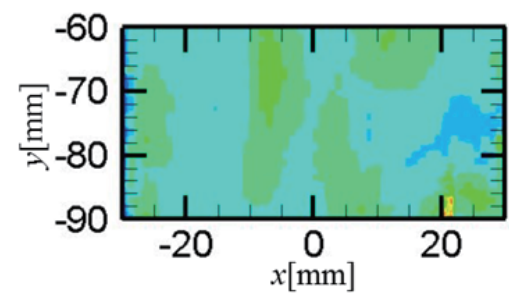

(a) Condition $\mathrm{A}$

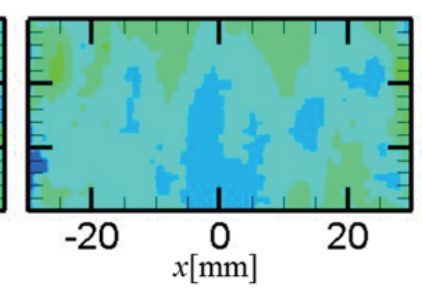

(b) Condition B

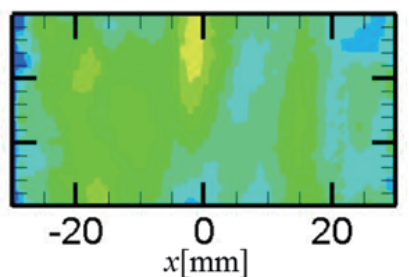

(c) Condition $\mathrm{C}$

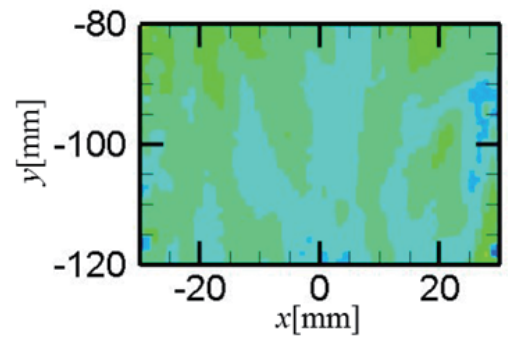

(d) Condition D

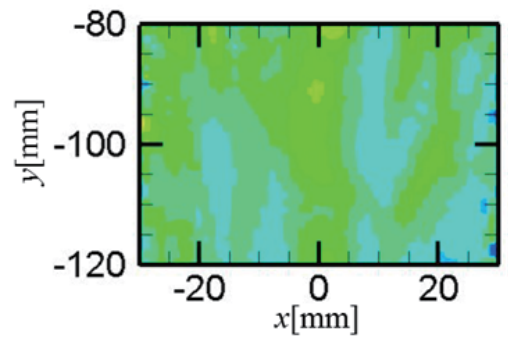

(e) Condition E

\section{$v_{\text {rms }}^{\prime}[-]$ \\ 0.2 \\ 0.18 \\ 0.16 \\ 0.14 \\ 0.12 \\ 0.1 \\ 0.08 \\ 0.06 \\ 0.04 \\ 0.02 \\ 0}

Fig.8 Turbulent intensity upstream flame tip.

に注目して考察を行う。図 7(d) と(e)は，未燃焼場におけ る計測と同様に，それぞれ"Slow”条件と”Fast”条件下の結 果である。燃料流量についても， $S=0.633$ における逆火 限界值（空気比 $\lambda=1.92 ）$ とし，未然焼場と同様である。 図 7(d)における $t=1155 \mathrm{~ms}$ では, 下流方向へ流れる未燃 予混合気が火炎先端に衝突し, 火炎先端の形状は, 下に凸 から平坦に変わっている. その後, 予混合気の流れと共に, 火炎は下流方向へ押し戻される. しかし, 火炎先端の上流 側に存在する未燃予混合気の流れ方向は常に下流方向之 はならず, $t=1230 \mathrm{~ms}$ における瞬時場のように上流方向 にもなるため, 火炎が上流側へ伝播することもあるが，全 体を通しては, 火炎が徐々に下流側へ押し戻されることが 観察された。一方, “Fast”条件下において旋回強さを弱め た結果である図7(e)についても， $t=486 \mathrm{~ms}$ において，下 流方向へ流れる未燃予混合気と火炎先端の衝突によって, その形状が平坦になっている. しかし, 図 7(d)と比べて, 未燃予混合気の下流方向への流れがより強く, 火炎もより 速い火炎伝播速度にて一気に下流方向へ伝播した。これも， 火炎の燃焼速度と火炎先端付近における未然予混合気の 流速とのつり合いによる影響と考えられる.しかし, "Slow" 条件または”Fast”条件に関わらず，火炎伝播速度は異なる ものの, 火炎を下流側へ押し戻し, また, その後, 保炎器 上にて火炎を保持するに至った。

ここで, 旋回強さを変化させたときにおける軸方向流速 の $\mathrm{rms}$ 值を乱流強度とし, 前述した既燃焼場において求 めたものを図 8 に示す. 対象とした時間は, 図 7 にて PIV 計測結果を示した時間である.乱流強度を示す範囲につい ては, PIV 計測にて火炎が存在した部分は未燃予混合気流 速が算出できないため, 火炎が存在しなかった上流側部分 のみを図 8(a) ( (e)に示す. 旋回強さを強める速さに関する 条件のみ異なった図 $8(\mathrm{a})$ と(b)を比較すると, ガラス管中
心軸では, ”Slow”条件下における乱流強度の方が比較的大 きいことがわかる。この結果は, 図 7(b)ではガラス管中心 軸に沿って逆流が安定的に存在する一方, 図 7(a)ではガラ ス管中心軸に沿って形成されている低速領域を遮るよう に, 下流方向への流れが時々存在していることからも妥当 であると言える。また，乱流強度が乱流燃焼速度に及ぼす 影響を考察するため, 乱流燃焼速度に影響を与える火炎面 密度について，既燃焼場における PIV 計測から得られた 火炎形状を用いて算出した。 火炎面密度とは火炎面面積を 火炎体積で割ったものである. 本来, 乱流火炎は非定常で 3 次元的な形状を持つが, 本実験における PIV 計測から得 られる火炎形状は瞬時の 2 次元的情報であるため, 近似的 に火炎面面積と火炎体積を以下の方法にて算出した。まず, 火炎面面積については, 火炎形状をスプライン曲線で近似 し, その曲線長さを測定して得られた火炎の周長を火炎面 面積として定義した。一方, 火炎体積については, 火炎部 分に含まれるピクセル数から算出した面積を火炎体積と して定義した，考慮する火炎形状の範囲は，PIV 計測によ って得られた範囲とし, 実験条件 $\mathrm{A} \sim \mathrm{C}$ では $y=0 \mathrm{~mm}$ か ら火炎先端まで, 実験条件 D, E では $y=-20 \mathrm{~mm}$ から火 炎先端までとした。これによって得られた火炎面密度につ いて, 図 7 で示した時閒帯の終点で考察する. 条件 A と B を比較すると, 終点における火炎面密度は $0.122 \mathrm{~mm}^{-1}$ と $0.110 \mathrm{~mm}^{-1}$ となった。 つまり, 条件 $\mathrm{A}$ の方が旋回強さの 変化を受けている間, 火炎面密度がわずかではあるが大き かったことが分かる。これは，条件 Bより Aにおいて乱 流強度が大きいため, 火炎面密度が比較的大きくなり, そ れによって乱流然焼速度は速くなったと考えられる. 図 7(a) と(b)において, 経過時刻の始点と終点で火炎幅を比較 すると, (a)の方が拡大しており, 燃焼速度が速い影響と 見られる。また，旋回強さを強める量が異なる図 8(c) と(b) 
の比較から，(c)では乱流強度が大きいことがわかる.この 条件 $\mathrm{C}$ においても, 乱流強度が乱流燃焼速度に与える影 響を考察するため, 図 7 の終点における火炎面密度を算出 すると $0.123 \mathrm{~mm}^{-1}$ となった。この結果は上述した実験条 件 $\mathrm{A}$ の值に近く, 図 7 において速い火炎伝播速度を伴っ て, 火炎が上流側へ伝播したことを考えると矛盾している ように考えられる.この原因としては以下のことが考えら れる. 図 8(c)の結果から, 条件 C では他の条件に比べると 乱流強度が大きいことが分かる，そのため，火炎伸張が発 生し, 火炎面密度は小さくなったと考えられる。つまり, 乱流強度が大きいことによる乱流燃焼速度の増加は小さ かったと推測できる，そのため，速い火炎伝播速度を伴っ て上流側一伝播した主な要因は, 上述した火炎の燃焼速度 と未燃予混合気流速のつり合いであると考えられる.

次に, 旋回強さを弱めた速さに関する条件のみが異なる 乱流強度を図 $8(\mathrm{~d})$ と (e)に示す。ここでは, 旋回強さを強 めた時とは異なり, ”Fast”条件下で乱流強度が大きくなる ことがわかり，特にガラス管中心軸付近に沿って顕著であ った。これは, ”Fast”条件下にて旋回強さを弱めた場合, 火炎を一気に下流へ押し戻した強い下流への未然予混合 気の流れによって, 速度が大きく変動したためと考えられ る。ここでも，上述と同様の方法を用いて，火炎面密度を 算出し, 乱流強度が乱流燃焼速度に与える影響を考察する. 図 7 の終点における火炎面密度は, 実験条件 D と E にお いてそれぞれ $0.221 \mathrm{~mm}^{-1}$ と $0.266 \mathrm{~mm}^{-1}$ となった.つまり， 実験条件 $\mathrm{E}$ では，図 7 で示した時間帯において火炎面密 度が大きかったと言える。これは, 条件 D に比べて条件 $\mathrm{E}$ では乱流強度が大きいため, 火炎面密度が旋回強さを変化 させている間，比較的大きかったと考えられる．これによ って, 乱流燃焼速度は速くなり, 実際に, 図 $7(\mathrm{~d})$ と (e)に おいて, 火炎の幅を経過時刻の始点と終点で比べると, 図 7(e)の方が広がっていることが分かる.

\section{4. 結論}

可変式旋回羽根付きスワーラを用い, 空気流量と空気比 一定の状態で, 燃焼器を模擬した円管内の旋回強さを独立 的に変化できるシステムを新たに構築した上, 高時間分解 能を有する時系列 PIV 計測により, 管内の旋回強さが変 化している間の予混合火炎の動的挙動について, 火炎周り の流れ場変化と共に同時に捉え, 両者の相互関係について 以下の知見を明らかにした。

（1）旋回強さを強めると, その強める速さに関わらず, 燃 焼器中心軸に沿って定常状態では見られない強い逆 流が一時的に観測された. 強める速さが速い条件では, 旋回強さを強めてから遅れが見られるものの, 逆流は 強くなり発生する時間帯も長くなるため, 火炎は途中 で留まることなく，上流側へ一気に伝播する。

（2）旋回強さを変化させる量による影響について, 旋回強
さを多く強めると, 一時的に観察される逆流はより強 くなるため, 火炎は速い火炎伝播速度を伴って上流側 へと伝播する.

（3）旋回強さを弱めると，その弱める速さに関わらず，一 時的に旋回流の渦構造が崩壊し, 燃焼器中心軸にまで 下流への流れが生成される. 旋回強さを弱める速さが 遅い場合は，下流への流れが断続的に現われ，火炎は 上下に行き来しながら下流側へと伝播していく. 一方 弱める速さが速いと, 旋回強さを弱めてから遅れて, より強い下流への流れが連続的に発生し. 火炎が一気 に下流側へ伝播した.

\section{参考 文 献}

1) Kurdyumov, V., Tarrazo, E. F., Truffaut, J. -M., Quinard, J., Wangher, A. and Searby, G. :Experimental and numerical study of premixed flame flashback, Proceedings of the Combustion Institute, Vol. 31 (2007) pp. 1275-1282.

2) Kröner, M., Fritz, J. and Sattelmayer, T. : Flashback limits for combustion induced vortex breakdown in a swirl burner, Proceedings of ASME TURBO EXPO 2002 (2002) Paper No. GT2002-30075.

3) Ishizuka, S. : Flame propagation along a vortex axis, Progress in Energy and Combustion Science, Vo1.28, No. 6 (2002) pp. 477-542.

4) Syred, N. : A review of oscillation mechanisms and the role of the precessing vortex core (PVC) in swirl combustion systems, Progress in Energy and Combustion Science, Vo1.32, No. 2 (2006) pp. 93-161.

5) Konle, M., Kiesewetter, F. and Sattelmayer, T. : Simultaneous high repetition rate PIV-LIF-measurements of CIVB driven flashback, Experiments in Fluids, Vol. 44 (2008) pp. 529-538.

6) Stöhr, M., Sadanandan, R. and Meier, W. : Experimental study of unsteady flame structures of an oscillating swirl flame in a gas turbine model combustor, Proceedings of the Combustion Institute, Vol. 32 (2009) pp. 2925-2932.

7) Owaki, T. and Umemura, A. :Premixed swirl combustion modes emerging for a burner tube with converging entrance, Proceedings of the Combustion Institute, Vo1.31 (2007) pp. 1067-1074.

8) Huang, Y. and Yang, V. : Effect of swirl on combustion dynamics in a lean-premixed swir1-stabilized combustor, Proceedings of the Combustion Institute, Vol. 30 (2005) pp. 1775-1782.

9）市川雄一，小宮山正治，小山敦史：希薄予混合燃焼器におけ る火炎伝播挙動に及ぼす旋回強さの影響, 日本機械学会論 文集, Vol.81, No.827 (2015) p. 14-00624.

10) Raffe1, M., Willert, C. and Kompenhans, J. : PIV の基礎 と応用, Springer (2000).

11) 可視化情報学会 : PIV ハンドブック, 森北出版 (2002).

12) Johnson, M. R., Littlejohn, D., Nazeer, W. A., Smith, K. 0. and Cheng, R. K. : A comparison of the flowfields and emission of high-swirl injectors and low-swirl injectors for lean premixed gas turbines, Proceedings of the Combustion Institute, Vol. 30 (2005) pp. 2867-2874. 